\title{
STATE OF THE ART OF “AMPHIBIAN" LOCALITIES OF THE LETOVICE SUBBASIN (BOSKOVICE BASIN, CZECH REPUBLIC)
}

\author{
Martina Krejčí \& Martin Mazuch
}

Institute of Geology and Palaeontology, Faculty of Science, Charles University, Albertov 6, 12843 Prague Czech Republic;

E-mail:krejcm@natur.cuni.cz,mazuch@natur.cuni.cz

\begin{abstract}
This paper provides a summary of localization of Permian historical sites in the Boskovice Basin, which yielded amphibians of the family Discosauriscidae. Most of these sites have not been previously precisely localized. Our investigation is focused mainly on so-called "Śpinar's localities" named after Prof. Z. Špinar and described in his work. Several sites were also described by A. Stehlik, J. Zajic \& S. Štamberg and J. Augusta. The reason for the localization of these locations is that more than 3,000 samples from these sites are stored at the Chlupáč's Museum of Earth History of the Charles University in Prague. Most localities are situated around the village of Bačov, where carbonization is the dominant type of preservation of Palaeozoic amphibian skeletons.
\end{abstract}

Key words: Palaeozoic, Permian, Carboniferous, Boskovice Basin, Letovice Subbasin, amphibian

\section{INTRODUCTION}

The Boskovice Basin and its sub-unit, the Letovice Subbasin, are important areas where large numbers of fossil remains of the Late Palaeozoic amphibians have been recorded in the past. These findings are dispersed in many collections of various institutions in the Czech Republic. A large number of amphibian fossil records from a part of the collections of Chlupáč's Museum of Earth History (CHMHZ) of the Charles University in Prague. The fossils came mostly from field works conducted during the 1950's and 1960's (Krejčí 2016, tab. 2). However, field research connected with fossil collecting has a history of about 150 years. The gradual decline in collecting activities, closing of some localities, the discovery of new sites and the use of different local names by various researchers have consequently led to inconsistent and erroneous labelling of the findings. This article focuses on cataloging and sorting of the localities of Letovice Subbasin area and simultaneously gives an overview of the current status of the localities. Hereby, we summarize locality data concerning fossil amphibian records.

Earliest studies on the geology of Boskovice Basin were published in the first half of the $19^{\text {th }}$ century and they were related to the mining indus- try of Carboniferous coal. Except information obtained from coal mine reports, other data were obtained from profiles, including parts along the river Oslava near the village of Oslavany. These profiles are of the late Gzhelian and early Asselian ages (Jaroš 1962, Šimůnek \& Martínek 2009). However, the earliest historical mentions of the Boskovice Basin are those of Zippe $(1835,1842)$ and Rittler (1853), who correlated sediments of the Rosice-Oslavany region with the Rotliengend strata in Germany.

The Boskovice Basin is famous for providing rich fossil fauna and flora (Štamberg \& Zajíc 2008). Vertebrates are represented by fishes, amphibians and rare reptiles. Invertebrates are mainly represented mainly insects. The first mention of these faunas dates back to the end of the $19^{\text {th }}$ century (Makowsky 1876). Systematic research, however, began only in the early the $20^{\text {th }}$ century and has continued to this day. More intense research was initiated Augusta (1926a, 1926b, 1933b, 1931), Stehlík (1924) and later built on by Špinar (1951a, 1951b, 1952a, 1952b, 1959), Kukalová (1955, 1963, 1964a, 1964b, 1965), Schneider (1980, 1984), Klembara \& Bartík (1999), Klembara \& Meszáros (1992), Zajíc (2000), 
Schneider \& Werneburg (2012) and Klembara (1997). Detailed reports are given in the works of Augusta (1933a, 1937a, 1937b), Havlena (1955) and most recently in a summary by Šmůnek \& Martínek (2009), and partly also by Pešek (2004).

\section{BIOSTRATIGRAPHY OF THE BOSKOVICE BASIN}

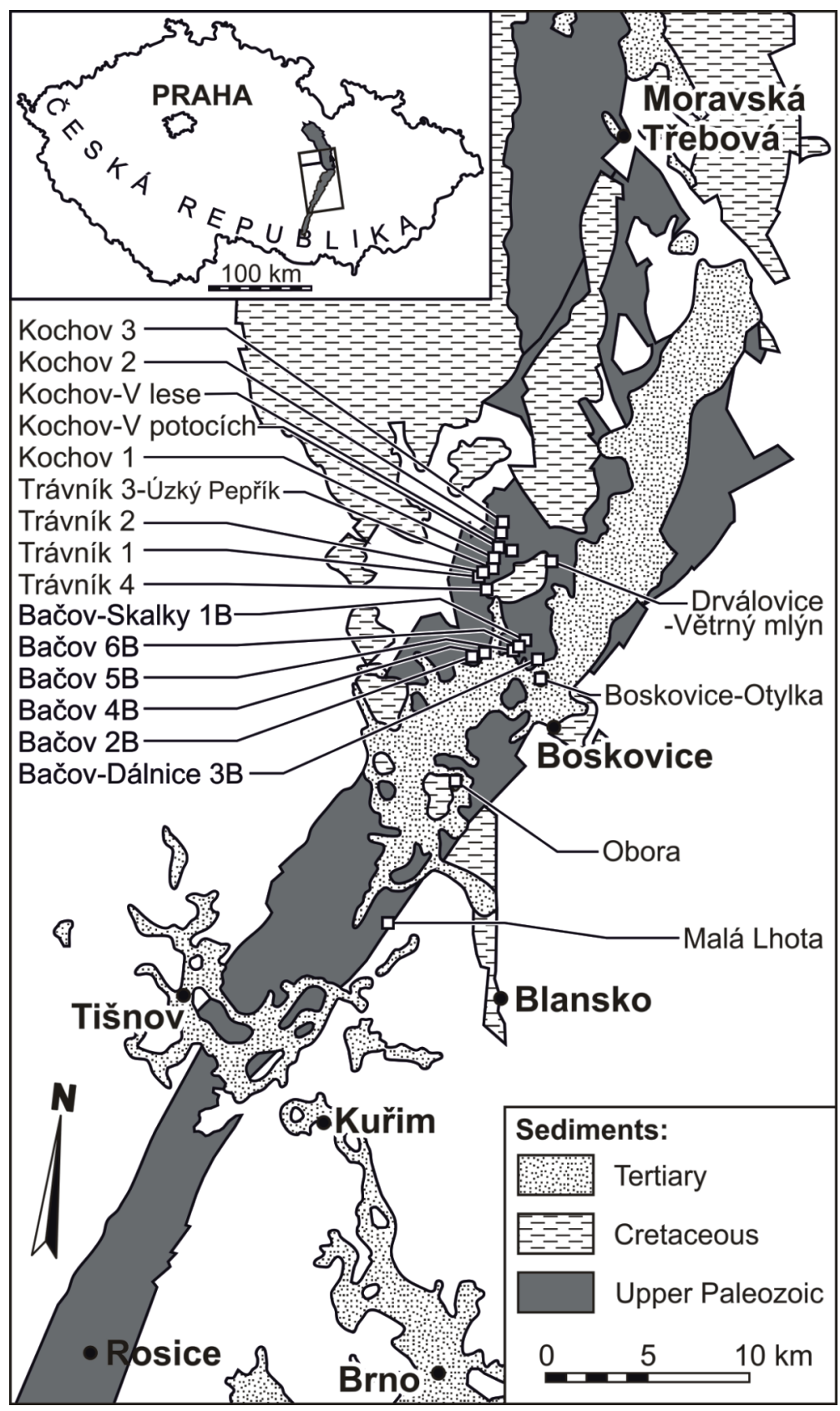

Figure 1. Simplified geological map and geographical distribution of fossil sites in the Letovice Subbasin.
The Boskovice Basin is located between the Moldanubicum and Moravosilesicum zones. In fact, the Boskovice Basin lies on the suture of these two regional structures (Pešek 2004). The Boskovice Basin was formed along the Main Boskovice fault which delineates the eastern edge of the Basin (Fig. 1). The Basin is divided into two subbasins, Rosice-Oslavany and Letovice. The Boskovice Basin is composed of four formations: Rosice-Oslavany, Padochov, VeverskáBítýška and Letovice. The amphibianbearing localities belong to the Letovice Formation.

The main Carboniferous fossiliferous part of the Boskovice Basin is concentrated into grey layers of Rosice-Oslavany coal seams, especially to the black shales and some intercalated embedded clastic sediments. In the Permian deposits, the main fossiliferous layers are grey in colour and they are several meters to several tens of meters thick lacustrine deposits of Padochov, Veverská Bitýška and Letovice formations (Šimůnek \& Martínek 2009). Fossiliferous are also hundreds of meters thick red beds which contain poorly preserved plant remains referred to genera Walchia and Cordaites (Rieger 1965). Fossiliferous horizons, however, thin and infrequently distributed within the red beds strata, ranging from the Late Carboniferous to the Early Permian in age. The upper part of the Letovice Formation provided valuable information about plant and animal assemblages and changes in the composition of communities from the Late Gzhelian to the Cisuralian. Key information for the stratigraphically older part of the Basin are provided by macroflora, whose character allows its assignment to existing plant zones (Wagner 1984, Wagner \& ÁlvarezVázquez 2010). On the other hand, in the Permian succession of the Basin, plant zones are less reliable and faunal associations are thus more important for biostratigraphy (Zajíc 2000, Schneider \& Werneburg 2012, Štamberg 2013, 2014; see Tab. 1 herein). 
Table 1. Stratigraphic chart of the Boskovice Basin/Letovice Subbasin (after Štamberg \& Zajíc 2008).

\begin{tabular}{|c|c|c|c|c|c|c|c|c|}
\hline \multicolumn{3}{|c|}{ Global units } & \multicolumn{2}{|c|}{ Regional stages } & \multicolumn{3}{|c|}{ Boskovice Basin } & \multirow[b]{2}{*}{ Biozone } \\
\hline System & $\begin{array}{c}\text { Series/ } \\
\text { Subsystem }\end{array}$ & Stage & Stage & Substage & Formation & Member & Horizon & \\
\hline \multirow{5}{*}{ Permian } & \multirow{5}{*}{ Cisuralian } & Artinskian & $\begin{array}{c}\text { Upper } \\
\text { Rotliengend }\end{array}$ & & \multirow{3}{*}{ Letovice } & Upper & & \\
\hline & & Sakmarian & \multirow{4}{*}{$\begin{array}{c}\text { Lower } \\
\text { Rotliengend }\end{array}$} & & & Middle & $\begin{array}{l}\text { Bačov } \\
\text { Míchov } \\
\text { Kochov }\end{array}$ & $\begin{array}{c}\text { Xenachanthus } \\
\text { decheni }\end{array}$ \\
\hline & & \multirow{3}{*}{ Asselian } & & & & Lower & $\begin{array}{c}\text { Lubě } \\
\text { Zboněk-Svitávka } \\
\text { Zbraslavec } \\
\end{array}$ & \multirow{3}{*}{$\begin{array}{l}\text { Acanthodes } \\
\text { gracilis }\end{array}$} \\
\hline & & & & & $\begin{array}{l}\text { Veverská } \\
\text { Bítýška }\end{array}$ & & Chudčice & \\
\hline & & & & & Padochov & & $\begin{array}{l}\text { Říčany } \\
\text { Zbýšov }\end{array}$ & \\
\hline $\begin{array}{l}\text { Carboni- } \\
\text { ferous }\end{array}$ & $\begin{array}{c}\text { Pennsylvan- } \\
\text { ian }\end{array}$ & Gzhelian & Stephanian & $\mathrm{C}$ & $\begin{array}{l}\text { Rosice- } \\
\text { Oslavany }\end{array}$ & & $\begin{array}{c}\text { Rosice-Oslavany } \\
\text { Helmhacker }\end{array}$ & $\begin{array}{l}\text { Sphaerolepis - } \\
\text { Elonichtys }\end{array}$ \\
\hline
\end{tabular}

\section{LOCALITIES}

In the following section we list the localities where the Late Palaeozoic amphibian fauna was found in the Boskovice Basin (Fig. 2). The summary includes information about historical localities described in the past, as well as those discovered recently.

Localities are listed in an alphabetical order and their description is structured as follows: brief geographical location, lithology, general remarks, references and list of recorded fossil species. The references are ordered chronologically. The original locality name or names used in a publication follows respective authors. Translations into English are placed in square brackets. For localities described by Špinar (1952a, 1952b), abbreviated names used by the author are given in brackets. All coordinates are read from map.

\section{LIST OF LOCALITIES}

\section{Bačov - Na Skalkách or Skalky (B1)}

Geography: Třetí lom [The Third Quarry] is located to the south of the dirt road from Vísky to Sudice, in the forested slope above the Bačov Creek, $500 \mathrm{~m}$ west of the centre of the Bačov village (Plate I, Fig. 3) (coordinates: N 49 31' 37.8", E $16^{\circ}$ $38^{\prime} 09.6^{\prime \prime}$ refer to central part of the locality). This locality is nowadays called "the Nature Monument Bačov" and the Bačov Hill is a local and historical name for this hill.

Lithology: Heavily bituminous limestone with spots of grey clay (Plate II, Fig. 1).

Remark: Palaeontological type of locality. One of the earliest studied fossiliferous localities in the studied region.

References: Augusta (1926b, 1936, 1948), Daňková (1950), Špinar (1950, 1951a, 1951b, 1952a), Havlena \& Špinar (1956a, 1956b), Zajíc \& Štamberg (1986), Roček (1988), Klembera \& Meszároš (1992), Ivanov (2003), Zajíc \& Štamberg (2004), Štamberg (2007), Šimůnek \& Martínek (2009).

List of amphibian species:

Discosauriscus austriacus Makowsky, 1876

Discosauriscus pulcherrimus Fritsch, 1879

Discosaursicus sp.

\section{Bačov (B2)}

Geography: In a valley of a nearby road from Chrudichromy to Bačov, about $1,200 \mathrm{~m}$ to the southsouth-west of Bačov (coordinates: N 49 $30^{\circ} 56.0^{\prime \prime}$, E $16^{\circ} 38^{\prime} 14.6^{\prime \prime}$ refer to upper part of the valley). Lithology: Heavily bituminous limestone with spots of grey clay.

Remark: The locality used as a technical site for the deposition of material at planned highway construction; exact localization is currently unknown. 


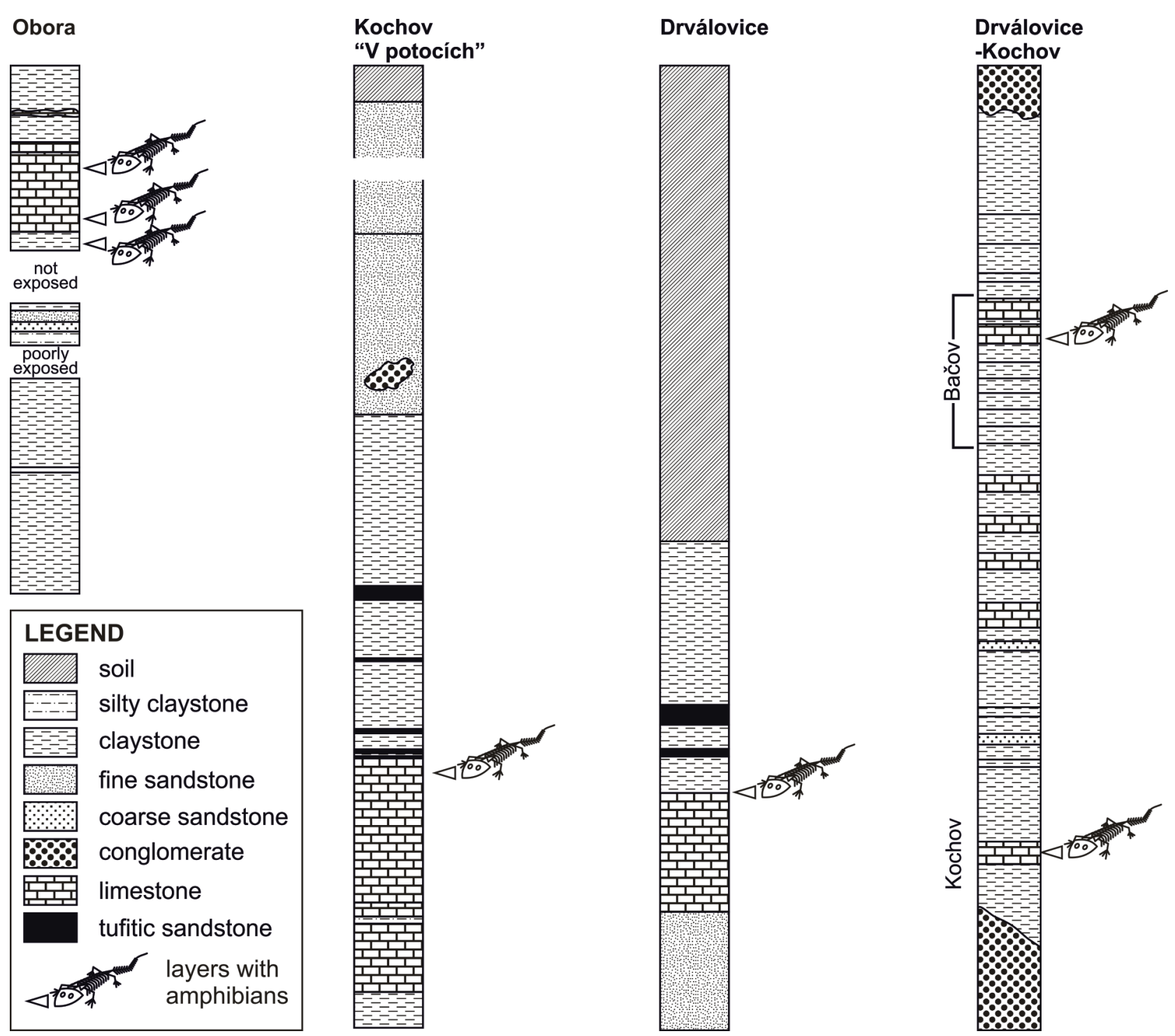

Figure 2. Recorded profiles of some locations with marked layers of preserved amphibian fossils. Modified after Dostál (2003a, 2003b) and Stamberg (2007).

Reference: Špinar (1952a).

List of amphibian species:

Discosauriscus austriacus Makowsky, 1876

\section{Bačov - Dálnice (B3)}

Geography: Field near ramp to a bridge of an unfinished highway across the Semíc Creek about $800 \mathrm{~m}$ to the south-south-east of the village of Bačov (Plate I, Fig. 1) (approx. coordinates: N $49^{\circ}$ $\left.31^{\prime} 08.5^{\prime \prime}, \mathrm{E} 16^{\circ} 38^{\prime} 47.6^{\prime \prime}\right)$.

Lithology: Heavily bituminous limestone with spots of grey clay (Plate II, Fig. 2).
Remark: Located where there were roadworks on the highway.

Reference: Špinar (1952a).

List of amphibian species:

Discosauriscus austriacus Makowsky, 1876

Discosauriscus sp.

\section{Bačov (B4)}

Geography: Valley of the Semíc Creek $600 \mathrm{~m}$ to the south-south-west of the center of the village of Míchov (coordinates: N $49^{\circ} 31^{\prime}$ 08.9", E $16^{\circ} 36^{\prime}$ $33.9 ")$. 

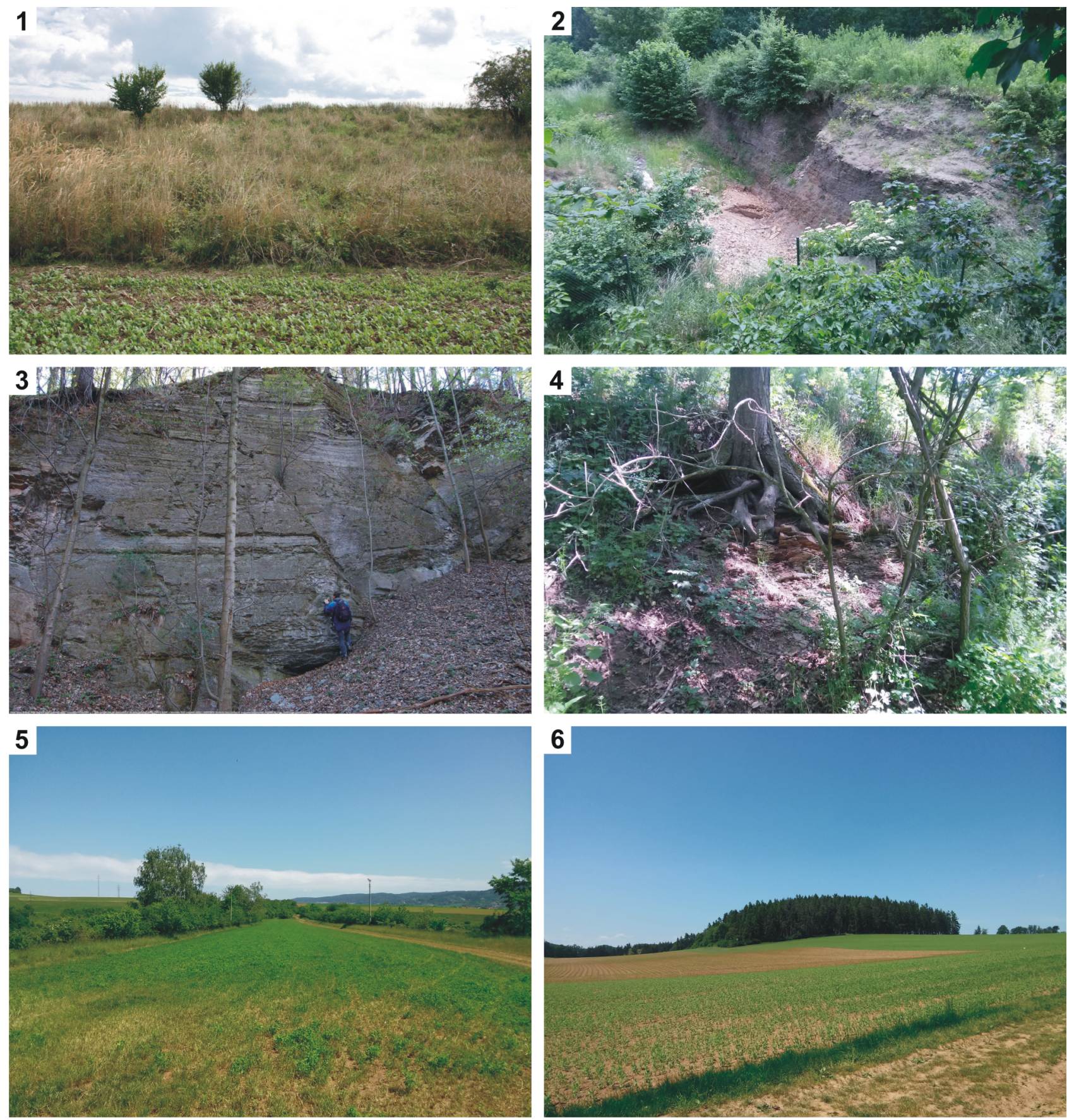

Plate I Recent preservation of localities of the Letovice Subbasin. 1 - Bačov-Dálnice (B3); 2 - Obora; 3 - Bačov Na Skalkách (B1); 4 - Bačov (B6); 5 - View of surrounding of Boskovice-Otylka; 6 - Kochov (K3). (Photos 1-2 and 4-6 by M. Krejčí, 3 after Gilíková, 2007.)

Lithology: Heavily bituminous limestone with spots of grey clay.

Remark: Paleontological site on the eastern hill slope discovered in 1952.
Reference: Špinar (1952a).

List of amphibian species:

Discosauriscus austriacus Makowsky, 1876

Discosauriscus sp. 

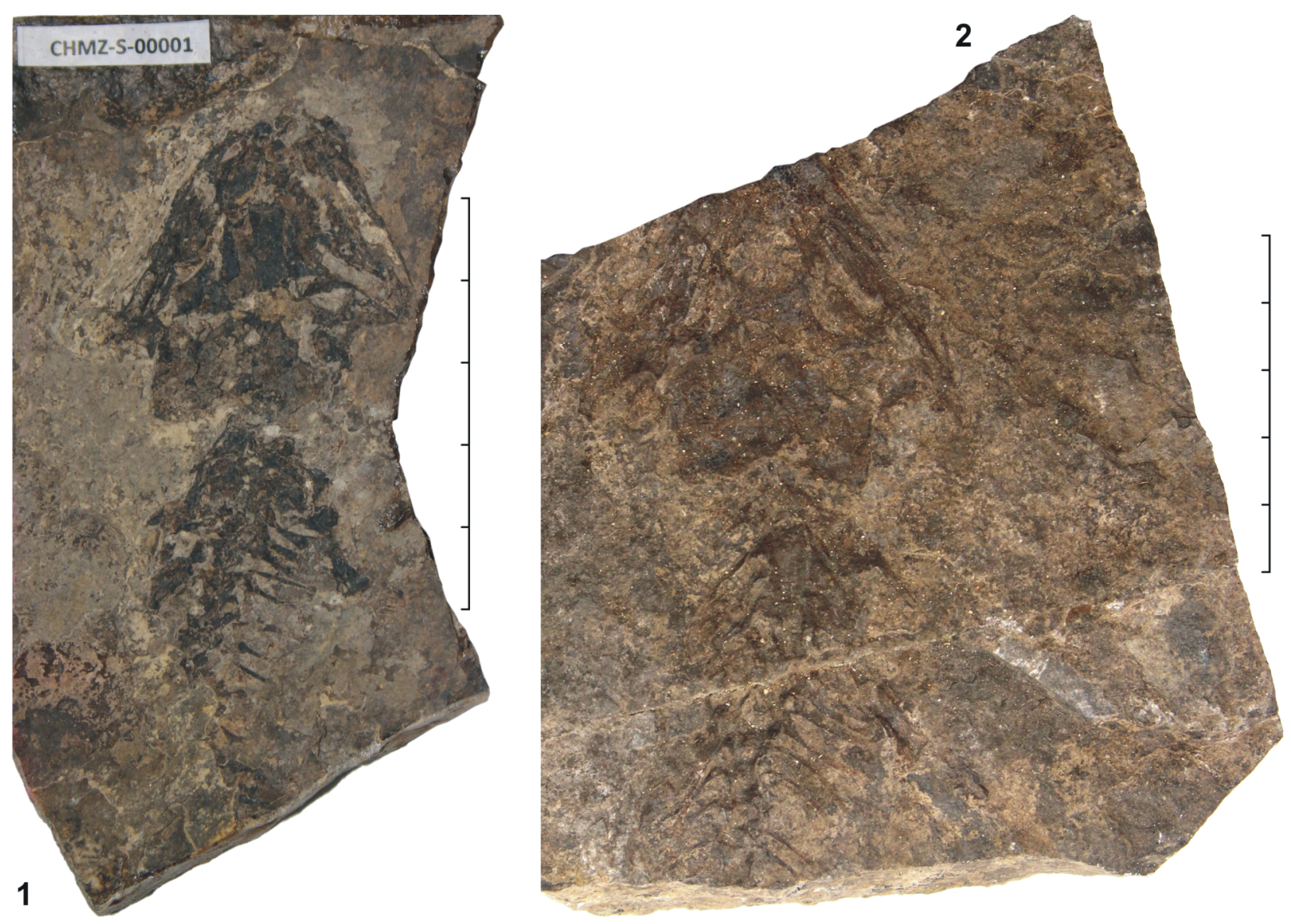

Plate II Examples of amphibians from the Letovice Subbasin. 1 - Specimen from Bačov - Na Skalkách (B1); 2 - Specimen from Bačov - Dálnice (B3). Scale bars equal $5 \mathrm{~cm}$. (All photos by M. Krejčí.)

\section{Bačov (B5)}

Geography: Excavations situated $1,100 \mathrm{~m}$ to the west-south-west of the centre of the village of Bačov, $150 \mathrm{~m}$ to the north of the settlement Pod Bačovem, on the west side at dirt road from Míchov to Bačov.

Lithology: Heavily bituminous limestone with spots of grey clay.

Remark: The locality comprises two outcrops about $25 \mathrm{~m}$ apart. The first outcrop is a small trench and the second is an outcrop in the slope. Špinar (1952a) addressed them as $5 \mathrm{Ba}$ and $5 \mathrm{Bb}$. (Coordinates: N $49^{\circ} 31^{\prime} 21.1^{\prime \prime}, \mathrm{E} 16^{\circ} 37^{\prime} 40.5^{\prime \prime} \mathrm{E}$ and $\mathrm{N} 49^{\circ} 31^{\prime} 21.8^{\prime \prime}$, E $16^{\circ} 37^{\prime} 41.1^{\prime \prime}$.)

Reference: Špinar (1952a).

List of amphibian species:

Discosauriscus austriacus Makowsky, 1876

Discosauriscus sp.

\section{Bačov (B6)}

Geography: $200 \mathrm{~m}$ long shallow gorge (axis of the gorge is approximately SSE-NNW) on the northern side on a dirt road from Míchov to Bačov, approximetaly $800 \mathrm{~m}$ to the west-south-west of the village centre of the Bačov (Plate I, Fig. 4). (Coordinates: $\mathrm{N} 49^{\circ} 31^{\prime} 26.1^{\prime \prime}, \mathrm{E} 16^{\circ} 37^{\prime} 55.3^{\prime \prime}$ refer to southernmost margin of the gorge.)

Lithology: Bituminous shale.

Remark: The fossiliferous located $25 \mathrm{~cm}$ below the surface and appears in a series of small outcrops along the length of the gorge.

Reference: Špinar (1952a).

List of amphibian species:

Discosauriscus austriacus Makowsky, 1876

Discosauriscus sp. 


\section{Boskovice - U Otylky}

Geography: Temporary outcrop "U Otylky" is named after "St. Otyllia Chapel" (coordinates: N $\left.49^{\circ} 30^{\prime} 37.9^{\prime \prime}, \mathrm{E} 16^{\circ} 39^{\prime} 02.2^{\prime \prime}\right)$ between Bačov and Boskovice, 2,500 m north-north-west of the centre of Boskovice and 1,800 $\mathrm{m}$ to the south-south-east of the centre of Bačov (Plate I, Fig. 5).

Lithology: Limestone with a insignificant admixture of dispersed clay.

Remark: Collected specimens were discovered during a field excavation around the outcrop.

Reference: Havlena \& Špinar (1956a).

List of amphibian species:

Discosauriscus austriacus Makowsky, 1876

Discosauriscus sp.

\section{Drválovice}

Geography: Surroundings of a dirt road $500 \mathrm{~m}$ to the west-west-south of the centre of Drválovice; situated near an old windmill which has not been preserved (approx. coordinates: N $49^{\circ} 33^{\prime} 49.4^{\prime \prime}$, E $\left.16^{\circ} 38^{\prime} 33.7^{\prime \prime}\right)$.

Lithology: $26 \mathrm{~cm}$ thick layer of limestone, claystone.

Remark: The fossiliferous horizon contains a fossil association similar to that known from Kochov - V Potocích.

References: Augusta (1936), Zajíc \& Štamberg (2004), Štamberg (2007), Štamberg \& Zajíc (2008). List of amphibian species:

Discosauriscus austriacus Makowsky, 1876

Discosauriscus sp.

\section{Kochov (K1)}

Geography: Field $400 \mathrm{~m}$ to the south-west of "Church of St. George" in the village of Kochov (coordinates: N 49 33' 45.4", E $\left.16^{\circ} 36^{\prime} 27.4^{\prime \prime}\right)$.

Lithology: Limestone with a insignificant admixture of dispersed clay.

Remark: Phosphatization is a dominant mode of preservation of amphibians.

References: Augusta \& Pokorný (1951), Špinar (1952a).

List of amphibian species:

Discosauriscus austriacus Makowsky, 1876

Discosauriscus sp.

\section{Kochov (K2)}

Geography: Road in the forest to the north of Kochov (coordinates: $\mathrm{N} 49^{\circ} 34^{\prime} 27.5^{\prime \prime}, \mathrm{E} 16^{\circ} 36^{\prime} 35.5^{\prime \prime}$ ), approximately $1,100 \mathrm{~m}$ to the north of the Kochov cemetery.

Lithology: Limestone with a small admixture of dispersed clay.

Remark: Phosphatization is the dominant type of preservation of the vertebrate material.

Reference: Špinar (1952a).

List of amphibian species:

Discosauriscus austriacus Makowsky, 1876

Discosauriscus sp.

\section{Kochov (K3)}

Geography: In the field under hump about 1,000 m to the east-south-east of the belfry of the village of Novičí (accidental finding in the field during agricultural work) (coordinates: N 49 $34^{\prime} 46.9^{\prime \prime}$, $\mathrm{E} 16^{\circ} 36^{\prime} 36.7^{\prime \prime}$ refer to center of the field).

Lithology: Limestone with a insignificant admixture of dispersed clay (Plate I, Fig. 6).

Remark: Phosphatization is a dominant mode of preservation of amphibians.

Reference: Špinar (1952a).

List of amphibian species:

Discosauriscus austriacus Makowsky, 1876

Discosauriscus sp.

\section{Kochov - V lese}

Geography: Excavated pit in the forest dating back to the beginning of the $21^{\text {st }}$ century, which backfilled today; $1,000 \mathrm{~m}$ north of Kochov church (coordinates: $\left.\mathrm{N} 49^{\circ} 34^{\prime} 25.1^{\prime \prime}, \mathrm{E} 16^{\circ} 36^{\prime} 53.2^{\prime \prime}\right)$.

Lithology: Limestone with a insignificant admixture of dispersed clay.

Remark: Phosphatization is the dominant type of preservation of vertebrates at fifth layer, in other layers, only carbonization occurs.

References: Zajíc \& Štamberg (2004), Klembara (2005, 2009), Štamberg \& Zajíc (2008).

List of amphibian species:

Makowskia laticephala (Klembara, 2005); one specimen, holotype kept at the Slovak National Museum in Bratislava (Slovakia)

Spinarerpeton brevicephalum (Klembara, 2009); one specimen, holotype kept at the Slovak National Museum in Bratislava (Slovakia)

\section{Kochov - V potocích}

Geography: Excavated pit in the forest dating back to the beginning of the 21st century, which backfilled today. At the margin at field, on the slope of 
a valley of the Třebětínka stream; $1,000 \mathrm{~m}$ to the north-north-west of the Kochov church (coordinates: $\left.\mathrm{N} 49^{\circ} 34^{\prime} 24.7^{\prime \prime}, \mathrm{E} 16^{\circ} 36^{\prime} 16.8^{\prime \prime}\right)$.

Lithology: Limestone with a insignificant admixture of dispersed clay.

Remark: Phosphatization is the dominant type of preservation (in the fifth layer), in other layers, only carbonization occur; artificial outcrop Zajíc \& Štamberg (2004).

References: Zajíc \& Štamberg (2004), Štamberg \& Zajíc (2008).

List of amphibian species:

Discosauriscus austriacus Makowsky, 1876

Discosauriscus sp.

\section{Malá Lhota}

Geography: Exact location is unknown. Probably a field near villages of Černá hora and Malá Lhota. Lithology: Grey, bituminous, clayey limestone.

Remark: This is one of the localities from which amphibian finds were collected already in the $19^{\text {th }}$ century but the locality itself was not described and its exact location are not known today.

References: Makowsky (1876), Augusta (1936).

List of amphibian species:

Discosauriscus pulcherrimus (Fritsch, 1879)

\section{Obora (in some literature called Jabloňany)}

Geography: Field and outcrop 1,000 $\mathrm{m}$ to the south-west of the village of Jablonnany and $1,000 \mathrm{~m}$ north-east of the village of Obora (Plate I, Fig. 2). (Coordinates: $\mathrm{N} 49^{\circ} 27^{\prime} 34.2^{\prime \prime}$, E $16^{\circ} 36^{\prime} 8.3^{\prime \prime}$ refer to outcrop.)

Lithology: Limestone with a insignificant admixture of dispersed clay.

Remark: Carbonization is a typical mode of preservation of amphibian. The material is labeled only as Obora or Jabloňany but the names do not appeear simultaneously on the same sample. The fossiliferous layer with amphibians is located just below the topsoil.

References: Kukalová (1960, 1963, 1964a, 1964b, 1965, 1969), Havlena \& Špinar (1961), Zídek (1966), Kukalová-Peck (1972, 1974), Schneider (1980, 1984), Holub \& Kozur (1981a, 1981b), Zajíc \& Štamberg (1986), Dostál (2003a, 2003b), Ivanov (2003), Zajíc \& Štamberg (2004), Šimůnek \& Martínek (2009).

List of amphibian species:

Discosauriscus austriacus Makowsky, 1876

Discosauriscus sp.
The following is a list of localities referred to as Trávník which is today a part of the village Kladoruby. Trávník was a separated village until the early 1950s. All samples of fossil amphibians were collected in the fields, and thus the approach to these localities is problematic.

\section{Trávník (T1)}

Geography: Field $700 \mathrm{~m}$ west-south-west of Chapel in Kladoruby (accidental finding in the field during agricultural work) (coordinates: N 49 $33^{\prime} 11.1^{\prime \prime}$, $\mathrm{E} 16^{\circ} 35^{\prime} 54.2^{\prime \prime}$ refer to approximate center of the field).

Lithology: Spotted clayey limestone.

Remark: The locality is known as a field belonging to the farmer Mr. Šrůček in old literature.

Reference: Špinar (1952a).

List of amphibian species:

Discosauriscus austriacus Makowsky, 1876

Discosauriscus sp.

\section{Trávník (T2)}

Geography: Field near the above mentioned field; about $500 \mathrm{~m}$ north of the village of Kladoruby (coordinates: $\mathrm{N} 49^{\circ} 33^{\prime} 20.1^{\prime \prime}, \mathrm{E} 16^{\circ} 36^{\prime} 01.3^{\prime \prime}$ refer to approximate center of the field).

Lithology: Spotted clayey limestone.

Remark: Only a few amphibian fossils were found there.

Reference: Špinar (1952a).

List of amphibian species:

Discosauriscus austriacus Makowsky, 1876

Discosauriscus sp.

\section{Trávník (T3) - "Úzký pepřík"}

Geography: Probably a field to the south-west of the centre of the village of Trávník on the slope of the valley of the Kladorubka Creek. Exact distance from village is unknow, approximately $800 \mathrm{~m}$ to the south-west from the chapel in Kladoruby (approx. coordinates: $\mathrm{N} 49^{\circ} 33^{\prime} 04.5^{\prime \prime}, \mathrm{E} 16^{\circ} 35^{\prime} 53.7^{\prime \prime}$ refer to centre of the field).

Lithology: Bačov fossiliferous horizon, spotted clayey limestones.

Remark: Fossils poorly preserved.

Reference: Špinar (1952a).

List of amphibian species:

Discosauriscus austriacus Makowsky, 1876

Discosauriscus sp. 


\section{Trávník (T4)}

Geography: Field $950 \mathrm{~m}$ to the south of the the chapel in Kladoruby. Local name for this field is Vísecko. (Approx. coordinates: N 49 32' 47.6", E $16^{\circ} 36^{\prime} 29.7^{\prime \prime}$ refer to south part of the field.)

Lithology: Bačov fossiliferous horizon, spotted clayey limestone.

Remark: The fossiliferous layer is located just below the topsoil.

Reference: Špinar (1952a).

List of amphibian species:

Discosauriscus austriacus Makowsky, 1876

Discosauriscus sp.

\section{CONCLUSION}

This research deals with over 3,000 amphibian remains (Table 2) deposited at the CHMHZ of the Faculty of Science, Charles University Prague. The major aim is to localize these records as precisely as possible to existing localities. This study also shows that most samples do not have precise localization, as former collectors described the position of localities only very generally. Therefore, a lot of samples have only the localization reflecting the area of the nearest village/town, e.g. Bačov, etc. This problem concerns the majority of samples stored at the CHMHZ.

Table 2. Number of fossils of amphibians in the area of individual villages (adopted and modified after Krejčí, 2016).

\begin{tabular}{|c|c|}
\hline Area & Number of samples \\
\hline Bačov & 2969 \\
\hline Obora & 219 \\
\hline Drválovice & 12 \\
\hline Trávník & 47 \\
\hline Kochov & 5 \\
\hline Malá Lhota & 1 \\
\hline
\end{tabular}

We have confirmed a relatively poor state of the art of paleontological localities in the Boskovice Basin (from which the amphibian material deposited at the CHMHZ originated). Only two localities are protected as a natural heritage. One of them, Bačov - Na Skalkách or Skalky (B1) is protected by the law on enviromental protection. The second locality - Obora, is protected by the Masaryk University in Brno. However, the conditions at these sites are not optimal. Most of them are situated in fields which are used for agricultural purposes during the whole year. Thus, large excavations are impossible. Few localities, e.g. 6B or Kochov $\mathrm{V}$ lese, are open and fossiliferous layers are located near the topsoil but the localities are situated in forests or temporary creeks.

Most of the historical localities are probably lost and/or their location is unknown because earlier researchers did not use detailed localization in their publications. In younger literature, paleontological sites are better localized and described. Another problem related to the data in earlier literature comes from confusing use of different units of measurement. For example, Makowsky (1876) used miles instead of kilometres when referring to his localities. At the present, one mile corresponds to 1,609 metres but the Austrian mile at the end of the $19^{\text {th }}$ century had 7,586 metres (Hosch 1877). Thus, it is also necessary to search for specific systems of measurements from the past.

\section{ACKNOWLEDGEMENTS}

We would like to thank the Institute of Geology and Palaeontology, Faculty of Science, Charles University Prague for providing access to the collections. This work has been supported by the SVV project No. 260437 of the Charles University in Prague and PROGRES Q45 and the 324 Centre for Geosphere Dynamics (UNCE/SCI/006). We are grateful to Dr. Stanislav Štamberg for specifying some locations and Martina Aubrechtová for her kind language editing of the manuscript. We would like to thank both reviewers, namely Martin Košták and Petr Kraft, for valuable advice.

\section{REFERENCES}

Augusta, J. 1926a. Fauna v permu boskovické brázdy. Věstník klubu přirodovědeckého v Prostějově za rok 1922-25 19, 25-40.

Augusta, J. 1926b. Příspěvek k poznání povahy střední části Boskovické brázdy. Sborník Státniho geologického ústavu československé republiky $6,143-220$.

Augusta, J. 1931. O fosilních rybách v permu boskovické brázdy. Od Horácka k Poddyjí 8, 357-363.

Augusta, J. 1933a. Z dějin geologického a paleontologického badání v permokarbonu boskovické brázdy. Věstník klubu př́rodovědeckého v Prostějově $23,15-51$. 
Augusta, J. 1933b. O vyhynulých krytolebcích (Stegocephalech) a jejich zástupcích ve spodním permu moravském. Př́roda 26(5), 120-128.

Augusta, J. 1936. Die Stegocephalen aus dem unteren perm der Boskovicer Furche in Mahren. Práce geolicko-paleontologického Ústavu Karlovy Univerzity $v$ Praze, 1-64.

Augusta, J. 1937a. Z dějin stratigrafického výzkumu permokarbonu kamenouhelné pánve rosickooslavanské. Hornický věstník a hornické a hutnické listy 1937, 1-15, 23-24.

Augusta, J. 1937b. Über die Arten der Gattung Callipteris Bgt. aus dem Oberkarbon des Steinkohlenbeckens von Rosice und Oslavany in Mahren (Tschechoslowakei). Zentralblatt für Mineralogie, Teil II, 223-229.

Augusta, J. 1948. Dnešní stav našich znalostí o stegocephalech z moravského spodního permu. Př́irodovědní Sborník ostravského kraje 9, 81-101.

Augusta, J., Pokorný, V. 1951. Zpráva o paleontologických výzkumech v permu Boskovické brázdy. Věstník Ústředního ústavu geologického, XXVI, 6-9.

Daňková, S. 1950. Flora ze spodního permu u Bačova (Morava). Sborník Státního geologického ústavu Československé republiky, Oddíl paleontologický 17, 181-192.

Dostál, O. 2003a. Paleontologie lokality Obora. 75 pp. M.Sc. thesis. Masaryk University. Brno.

Dostál, O. 2003b. Zástupci čeledi discosauriscidae (Romer 1947) na lokalitě Obora. Geologické výzkumy na Moravě a ve Slezsku v r. 2002 10, 40-43.

Gilíková, H. 2007. Foto - Bačov. In: Fotoarchiv České geologické služby [online databáze]. Česká geologická služba [cit. 2019-07-04]. Available at http://www.geology.cz/foto/14074

Havlena, V. 1955. Vývoj stratigrafie permokarbonských uhelných oblastí Čech a Moravy. 100 pp. Ústřední ústav geologický. Praha.

Havlena, V., Špinar, Z. 1956a. Stratigrafie permských uloženin v území mezi Bačovem a Svitavkou na Moravě. Sborník Ústředního ústavu geologického 22, 7-48.

Havlena, V., Špinar, Z. 1956b. Biostratigrafický výzkum permu střední části Boskovické brázdy. Věstník Ústředního ústavu geologického 27, 123-125.

Havlena V., Špinar Z. 1961. Zpráva o paleontologicko-stratigrafickém výzkumu okolí Jabloňan u Skalice nad Svitavou. Zprávy o geologických výzkumech $v$ roce 1959, 70.

Holub, V., Kozur, H. 1981a. Revision einiger Conchostracen - Faunen des Rotliegenden und biostratigraphische Auswertung der Conchostracen des Rotliegenden. Geologisch-Paläontologische Mitteilungen Innsbruck 11(2), 39-94.

Holub, V., Kozur, H. 1981b. Arthropodenfaehrten aus dem Rotliegenden der ČSSR. GeologischPaläontologische Mitteilungen Innsbruck 11(3), 95-148.

Hosch, R. 1877. Fromme's Österreichischer Feuerwehr-Kalender, Jahrgang 1877, IV. Jahrgang. 183 pp. Wien.

Ivanov, M. 2003. Přehled historie paleontologického bádání v permokarbonu boskovické brázdy na Moravě. Acta Musei Moraviae, Scientiae geologicae, Brno, 88(1), 3-112.

Jaroš, J. 1962. Geologický uývoj a stavba boskovické brázdy. 195 pp. Ph.D. thesis, Charles University, Prague, Czech Republic.

Klembara, J. 1997. The cranial anatomy of Discosauriscus Kuhn, a seymouriamorph tetrapod from the Lower Permian of the Boskovice Furrow Czech Republic. Philosophical Transactions of the Royal Society of London B 352, 257-302.

Klembara, J. 2005. A new discosauriscid seymouriamorph tetrapod from the Lower Permian of Moravia, Czech Republic. Acta Palaeontologica Polonica 50(1), 25-48.

Klembara, J. 2009. The skeletal anatomy and relationships of a new discosauriscid seymouriamorph from the Lower Permian of Moravia Czech Republic. Annals of Carnegie Museum 77(4), 451-483.

Klembara, J., Bartik, I. 1999. The postcranial skeleton of Discosauriscus Kuhn, a seymouriamorph tetrapod from the Lower Permian of the Boskovice Furrow (Czech Republic). Earth and Environmental Science Transactions of The Royal Society of Edinburgh 90(4), 287-316.

Klembara, J., Meszároš, Š. 1992. New finds of Discosauriscus austriacus (Makowsky 1876) from the Lower Permian of Boskovice Furrow (Czecho-Slovakia). Geologica Carpathica 43(5), 305-312.

Krejčí, M. 2016. Surchnopaleozoičtí obojživelníci boskovické brázdy v sbírkovém materiálu Chlupáčova muzea. 80 pp. M.Sc. thesis. Charles University Prague. Czech Republic. 
Kukalová, J. 1955. Permoedischia n.g. (Protorthoptera) a Moraviptera n.g. (Palaeodictyoptera) z moravského permu. Sborník Ústředního ústavu geologického, Oddíl paleontologický 21, 541575.

Kukalová, J. 1960. New Palaeodictyoptera of the Carboniferous and Permian of Czechoslovakia. Sborník Ústredního ústavu geologického, Oddíl paleontologický 25, 239-251.

Kukalová, J. 1963. Permian Insects of Moravia. Part I - Miomoptera. Sborník geologických věd, Paleontologie 1, 7-52.

Kukalová, J. 1964a. Permian Insects of Moravia. Part II - Liomopteridae. Sborník geologických věd, Paleontologie 3, 3-118.

Kukalová, J. 1964b. Review of the Calvertiellidae, with description of a new genus from Permian strata of Moravia (Paleodictyoptera). Psyche: A Journal of Entomology 71(4), 153-168.

Kukalová, J. 1965. Permian Protelytroptera, Coleoptera and Protorthoptera (Insecta) of Moravia. Sborník geologických věd, Paleontologie 6, 61-98.

Kukalová, J. 1969. On the systematic position of the supposed Permian beetles Tschecardocoleidae, with a description of a new collection from Moravia. Sborník geologických věd, Paleontologie 11, 139-162.

Kukalová-Peck, J. 1972. Unusual Structures in the Paleozoic Insect Orders Megasecoptera and Palaeodictyoptera, with a Description of a New Family. Psyche: A Journal of Entomology 79(3), 243-268.

Kukalová-Peck, J. 1974. Wing-folding in the Paleozoic Insect Order Diaphanopterodea (Paleoptera), with a Description of New Representatives of the Family Elmoidae. Psyche: A Journal of Entomology 81(2), 315-333.

Makowsky, A. 1876. Über einen neuen Labyrinthodonten: "Archegosaurus austriacus nov. spec". Sitzungsberichte der Kaiserlichen Akademie der Wissenschaften. Mathematisch-Naturwissenschaftliche Classe 73, 155-166.

Pešek, J. 2004. Late Palaeozoic limnic basis and coal deposits of the Czech Republic. Folia Musei Rerum Naturalium Bohemiae Occidentalis, Geologica 1, 1-188.

Rieger, Z. 1965. Nove fytopaleontologické nálezy v rosicko-oslavanské oblasti. Časopis pro mineralogii a geologii 10(1), 89-91.
Rittler, J. 1853. Bemerkungen uber das mahrische Steinkohlengebirge und die Kohlengruben nachst Brunn in Mahren. Österreichische Zeitschrift Berg- und Hüttenwesen 1, 340-341, 345-347.

Roček, Z. 1988. List of fossil amphibians of Czechoslovakia. Acta Zoologica Cracoviensia 31(19), 513-540.

Schneider, J.W. 1980. Zur Entomofauna des Jungpaläozoikums der Boskovicer Furche (ČSSR), Teil 1: Mylacridae (Insecta, Blattoidea). Freiberger Forschungshefte C 357, 43-55.

Schneider, J.W. 1984. Zur Entomofauna des Jungpaläozoikums der Boskovicer Furche ČSSR, Teil 2: Phyloblattidae (Insecta, Blattoidea). Freiberger Forschungshefte C 395, 19-37.

Schneider, J.W., Werneburg, R. 2012. Biostratigraphie des Rotliegend mit Insekten und Amphibien, 110-142. In Lutzner, H. \& Kowalczyk, G. (eds) Deutsche Stratigraphische Kommission: Stratigraphie von Deutschland X. Rotliegend. Teil I: Innervariscische Becken. Schriftenreihe der Deutschen Gesellschaft für Geowissenschaften 61.

Stehlik, A. 1924. New Stegocephalians from Moravian Permian formations and additions to the knowledge of stegocephalians from Nýřany. Acta Societatas Scientiarum Naturalium MoravoSilesiacae 1, 199-283.

Šimůnek, Z., Martínek, K. 2009. A study of Late Carboniferous and Early Permian plant assemblages from the Boskovice Basin, Czech Republic. Review of Palaeobotany and Palynology 155, 275-307.

Špinar, Z.V. 1950. Krytolebec Melanerpeton longicaudatum Augusta, 1936. - Rozpravy České akademie věd a uměni, Třida II Matematickoprrirodovědecká 59(29), 1-26.

Špinar, Z.V. 1951a. Stratigraficko-paleontologické výzkumy v okolí Bačova a Trávníka. Věstník Ústředního ústavu geologického 26, 134-136.

Špinar, Z.V. 1951b. Několik nových poznatků o rodu Phaiherpeton Roemer, 1947. Sborník Ústředního ústavu geologického, Oddělení paleontologie 18, 481-500.

Špinar, Z.V. 1952a. Revise některých moravských Discosauriscidů (Labyrinthodontia). Rozpravy Ústredního ústavu geologického 15, 1-159.

Špinar, Z.V. 1952b. O nálezech moravských krytolebců. Vesmír 31(2), 50-51. 
Špinar, Z.V. 1959. Zpráva o paleontologických výzkumech v Boskovické brázdě. Zprávy o geologických výzkumech v roce 1957, 239-240.

Stamberg, S. 2007. Permo-Carboniferous Actinopterygians of the Boskovice Graben. Part 1. Neslovicella, Bourbonnella, Letovichthys, Elonichthys. 155 pp. Muzeum východních Čech v Hradci Králové. Hradec Králové.

Štamberg, S. 2013. Knowledge of the Carboniferous and Permian actinopterygian fishes of the Bohemian Massif - 100 years after Antonin Frič. Acta Musei Nationalis Pragae, Serie B, Historia Naturalis 69(3-4), 159-181.

Štamberg, S. 2014. Fossiliferous Early Permian horizons of the Krkonoše-Piedmont Basin and the Boskovice Graben (Bohemian Massif) in view of the occurrence of actinopterygians. Freiberger Forschungshefte C 548, 45-60.

Štamberg, S., Zajíc, J. 2008. Carboniferous and Permian faunas and their occurence in the limnic basins of the Czech Republic. 224 pp. Muzeum východních Čech v Hradci Králové. Hradec Králové.

Wagner, R.H. 1984. Megafloral zones of the Carboniferous. Compte rendu 9e Congrès International de Stratigraphie et de Géologie du Carbonifère Washington, 1979) 2, 109-134.

Wagner, R.H., Álvarez-Vázquez, C. 2010. The Carboniferous floras of the Iberian Peninsula: a synthesis with geological connotations. Review of Palaeobotany and Palynology 162, 239-324.
Zajíc, J. 2000. Vertebrate zonation of the nonmarine Upper Carboniferous-Lower Permian basins of the Czech Republic. Courier-Forschungsinstitut Senckenberg 223, 563-575.

Zajíc, J., Sttamberg, S. 1986. Summary of the Permocarboniferous freshwater fauna of the limnic Basins of Bohemia and Moravia. Acta Musei Reginaehradecensis, Series A: scientiae naturales 20, 61-82.

Zajíc, J., Štamberg, S. 2004. Selected important fossiliferous horizons of the Boskovice Basin in the light of the new zoopaleontological data. Acta Musei Reginaehradecensis, Series A: scientiae naturales 30, 5-15.

Zippe, F.X.M. 1835. Die Flötzgebirge Böhmens mit besonder Rücksicht auf die Kohlenführung. Neue Schriften der Kaiserlichen Königlichen Patriotich-Ökonomischen Gesellschaft Böhmen 5, 1-49.

Zippe, F.X.M. 1842. Die Steinkohlen, ihr Werth, ihre Wichtigkeit im Allgemeinen ind ihre Verbreitung in Böhmen. Zeitschrift Gewerbewesen 2, $1-55$.

Zídek, J.1966. Nové nálezy žralokovitých ryb skupiny Xenacanthodii ve spodním permu boskovické brázdy na Moravě. Časopis Národního muzea, Řada př́rodovědná. 135(2), 74-80. 